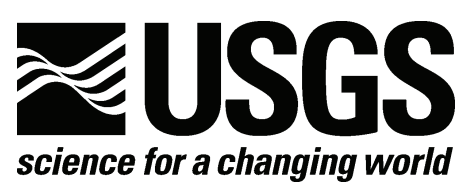

\title{
Seismic Constraints and Coulomb Stress Changes of a Blind Thrust Fault System, 1: Coalinga and Kettleman Hills, California
}

By Jian Lin ${ }^{1}$ and Ross S. Stein ${ }^{2}$

2006

Open-File Report 2006-1149

${ }^{1}$ Woods Hole Oceanographic Institution, Woods Hole, Mass.

2 U.S. Geological Survey, Menlo Park, Calif. 


\section{U.S. Department of the Interior \\ Dirk Kempthorne, Secretary}

\section{U.S. Geological Survey \\ P. Patrick Leahy, Acting Director}

U.S. Geological Survey, Reston, Virginia 2006

Revised and reprinted: 2006

For product and ordering information:

World Wide Web: http:/ / www.usgs.gov/pubprod/

Telephone: 1-888-ASK-USGS

For more information on the USGS - the Federal source for science about the Earth, its natural and living resources, natural hazards, and the environment:

World Wide Web: http:/ / www.usgs.gov/

Telephone: 1-888-ASK-USGS

Suggested citation:

Lin, J., and Stein, R.S., 2006, Seismic constraints and Coulomb stress changes of a blind thrust fault system, 1: Coalinga and Kettleman Hills, California: U.S. Geological Survey Open-File Report 2006-1149 17 p [available on the World Wide Web at URL

http:/ / pubs.usgs.gov/ of/2006/1149/ ].

Any use of trade, product, or firm names is for descriptive purposes only and does not imply endorsement by the U.S. Government.

Although this report is in the public domain, permission must be secured from the individual copyright owners to reproduce any copyrighted material contained within this report. 


\section{Summary}

This report reviews the seismicity and surface ruptures associated with the 1982-1985 earthquake sequence in the Coalinga region in California, and the role of Coulomb stress in triggering the mainshock sequence and aftershocks. The 1982-1985 New Idria, Coalinga, and Kettleman Hills earthquakes struck on a series of west-dipping, en echelon blind thrust faults. Each earthquake was accompanied by uplift of a Quaternary anticline atop the fault, and each was accompanied by a vigorous aftershock sequence. Aftershocks were widely dispersed, and are seen above and below the thrust fault, as well as along the up-dip and down-dip projection of the main thrust fault. For the Coalinga and Kettleman Hills earthquakes, high-angle reverse faults in the core of the anticlines are evident in seismic reflection profiles, and many of these faults are associated with small aftershocks. The shallowest aftershocks extended to within 3-4 $\mathrm{km}$ of the ground surface. There is no compelling evidence for aftershocks associated with flexural slip faulting. No secondary surface rupture was found on any of the anticlines. In contrast, the 1983 Nuñez rupture struck on a high-angle reverse fault $10 \mathrm{~km}$ west of the Coalinga epicenter, and over a 40-80-day period, up to $1 \mathrm{~m}$ of oblique surface slip occurred. The slip on this Holocene fault likely extended from the ground surface to a depth of $8-10 \mathrm{~km}$. We argue that both the Nuñez and Kettleman earthquakes were triggered by stresses imparted by the Coalinga mainshock, which was the largest of the four events in the sequence.

\section{Analysis of relationship of seismicity to the fold and fault structure}

The $1983 \mathrm{M}=6.7$ Coalinga earthquake is the largest in a sequence of four reverse faulting events that struck the eastern margin of the California Coast Ranges fold belt during 1982-1985 (Fig. 1) The three blind thrust events all occurred beneath growing anticlines, and all exhibited diffuse aftershocks (Fig. 2) The fold belt accommodates several millimeters per year of crustal shortening normal to the strike of the San Andreas fault, and the fold belt has been active for 2-3 Ma [Namson and Davis, 1988; Stein and King, 1984; Stein and Yeats, 1989; Rymer and Ellsworth, 1990; Wentworth and Zoback, 1990].

When the main fault ruptures, aftershocks, and geological structure interpreted from oil well and seismic reflection profiling are viewed together, all are seen to show highly diffuse seismicity that extends into the core of the anticline atop the thrust fault, and most show rootless high-angle reverse faults in the anticline as well, with some of these secondary faults being the site of aftershock activity. This is particularly clear for the 1983 Coalinga (Fig. 3b) and 1985 Kettleman Hills (Fig. 3c) earthquakes. 
All of the folds were uplifted by the blind thrust earthquakes, indicating that the anticlines grow through repeated earthquake events. Thus it is clear that the thrust faults have cumulative slip of 1-4 km based on the fold geometry [Fig. 3) [Ekström et al., 1992; Stein and Ekström, 1992]. A similar relation is seen for the $1987 \mathrm{M}=6.0$ Whittier Narrows earthquake beneath a Quaternary fold [Lin and Stein, 1989]. Close inspection of recently reprocessed seismic reflection profiles across the Coalinga anticline reveal gently folded strata with only minor high-angle reverse faulting in the anticlinal core Fig. 5).

Relocated seismicity and reanalyzed focal mechanisms associated with the $1985 \mathrm{M}=6.0$ Kettleman Hills earthquake indicate that reverse faulting is dominant, and that some of the back-thrusts and secondary faults extend from $10 \mathrm{~km}$ depth to as shallow as $3 \mathrm{~km}$. On the basis of seismicity alignments, it is likely that some slip occurred on these high-angle structures during the 1985 earthquake sequence Fig. 6). In the case of the 1983 Coalinga earthquake, few of the shallow aftershocks can be confidently ascribed to the high-angle reverse faults in the anticlinal core Fig. 7) Regardless of the true orientation and extent of the thrust fault, it is evident that seismicity extends both above and below the blind thrust, and is widely dispersed.

\section{The role of Coulomb stress in triggering the mainshock sequence and aftershocks}

Recently, we analyzed the 1982-1985 Coalinga sequence to understand how the earthquakes progressed to the southeast and to seek an explanation for the distribution of aftershocks [ Lin and Stein, 2004]. The sequence included not only the three blind faults but also the surface-cutting Nuñez rupture that occurred about a month after the Coalinga earthquake. Although stress transferred by the New Idria event to the Coalinga shock is negligible (Fig. 8a), the stress imparted by the Coalinga event to the Nuñez rupture plane is large (Fig. 9), suggesting that the Coalinga shock promoted the Nuñez earthquake. The Coulomb stress increase at the base of the Nuñez fault is about 4-10 bars Fig. 9a, b) and is unclamped by 20 bars, because of its proximity to the Coalinga source (Fig. 9d) These stresses should modestly increase and propagate outward with time, as a result of the viscoelastic relaxation of the asthenosphere [Freed and Lin, 1998]. This means that 2 years after the Coalinga earthquake, the stress at the future Nuñez and Kettleman Hills hypocenters was probably higher than it was immediately after the Coalinga mainshock.

Aftershocks of the New Idria and Coalinga events are concentrated in regions of calculated Coulomb stress increase (Fig. 8a, b) although this is less true for the Kettleman Hills aftershocks (Fig. 8c). In cross section, the distributed pattern of Coalinga aftershocks in the epicentral area Fig. 10a) and at the future epicenter of the Kettleman Hills shock Fig. 10b) are also in rough 
accord with the calculated Coulomb stress change. This furnishes additional support that aftershocks are the product of the coseismic stress changes, rather than being a continuation of the background seismicity.

\section{Surface rupture associated with the 1983 Coalinga earthquake}

The New Idria, Coalinga, and Kettleman Hills folds and surrounding basins were carefully checked for surface faulting, and none was found [Clark et al., 1983; Rymer et al., 1990a; Rymer and Sharp, oral commun., 1985]. The sole observation of surface rupture accompanying any of the 1982-1985 earthquakes come from the $1983 \mathrm{M}_{W}=5.2$ and $\mathrm{M}_{W}=6.0$ Nuñez shocks [Rymer et al., 1990a] [Fig. 11). Both the June 11 and July 22 events caused surface rupture and the July 22 event provided another slip pulse with afterslip [Rymer et al., 1990b].

The Nuñez is a high-angle reverse fault that lies $10 \mathrm{~km}$ west of the Coalinga mainshock and the Coalinga anticline, and its strike differs from the Coalinga shock by $30^{\circ}$ Fig. 9a). The Nuñez surface rupture was first seen 40 days after the Coalinga main shock, at the time of a shallow $M=5.2$ shock on the Nuñez fault; it probably did not slip at the time of the Coalinga mainshock. The largest $\mathrm{M}_{\mathrm{w}}=6.0$ shock on the Nuñez fault did not occur until 41 days later, or 81 days after the Coalinga mainshock [Rymer et al., 1990a] Fig. 11). The Nuñez fault was mapped and trenched after the 1983 rupture, and it was found to be an active feature with past Holocene slip [Rymer et al., 1990a]. The fact that the surface slip preceded, rather than followed, the $M=6.0$ mainshock is highly unusual and indicates more swarm-like behavior. The Nuñez fault displacements were also significant, at almost $1 \mathrm{~m}$, and, based on the alignment of seismicity with the surface slip, it is likely that the slip extends from the surface to a depth of $8-10 \mathrm{~km}$ [Rymer et al., 1990b].

Coulomb stress calculations suggest that the Nuñez rupture was promoted by strong unclamping stresses at the base of the fault, where it is located only $5 \mathrm{~km}$ west of the Coalinga

thrust fault Fig. 9d). Perhaps the unclamping caused the base of the fault to creep, with the creep propagating upwards over the 40 days between the Coalinga mainshock and when the surface rupture was first seen. Why the creep was followed by the $M=6.0$ shock remains mysterious.

Conclusions The 1982-1985 New Idria, Coalinga, and Kettleman earthquakes provide a beautiful example of blind thrust faults beneath growing en echelon anticlines that ruptured in a north-to-south sequence. In each case, the anticlines are simple Quaternary folds that are expressed in the surficial geology, topography, and geomorphology. All three earthquakes 
reveal the diagnostic features of blind thrust earthquakes: diffuse aftershock zones, high-angle reverse faults slipping in the anticlinal cores, but no surface rupture on the anticlines themselves. Our stress analysis suggests that the 1983 Nuñez and 1985 Kettleman Hills ruptures were likely promoted by Coulomb stress changes imparted by the Coalinga earthquake, but the Nuñez and Kettleman faults are quite different in character, the first being a high-angle reverse fault that ruptured to the surface, and the second being a deep blind thrust fault.

Acknowledgments. We thank Michael Rymer and James Lienkaemper for constructive reviews and Dan Scheirer for providing photo of the Kettleman Hills North Dome. This article is based on a project report to the Central Research Institute of Electric Power Industry (CRIEPI), Japan, Sub-Contract Order Number 10504206.

\section{References}

Ekström, G., R. S. Stein, J. P. Eaton, and D. Eberhart-Phillips (1992), Seismicity and geometry of a 110-km long blind thrust fault, 1, The 1985 Kettleman Hills, California, earthquake, J. Geophys. Res., 97, 4843-4864.

Freed, A. M., and J. Lin (1998), Time-dependent changes in failure stress following thrust earthquakes, J. Geophys. Res., 103, 24,393-324,409.

Guzofski, C., and J. H. Shaw (2003), Coalinga anticline, San Joaquin basin, California, U.S.A, in Seismic interpretation of contractional fault-related folds: An AAPG seismic atlas, edited by J. $\mathrm{H}$. Shaw, et al., pp. 138-140, Amer. Assn. Petrol. Geol., Tulsa.

Lin, J., and R. S. Stein (1989), Coseismic folding, earthquake recurrence, and the 1987 source mechanism at Whittier Narrows, Los Angeles Basin, California, J. Geophys. Res., 94, 9614-9632.

Lin, J., and R. S. Stein (2004), Stress triggering in thrust and subduction earthquakes, and stress interaction between the southern San Andreas and nearby thrust and strike-slip faults, J. Geophys. Res., 109, B02303, doi:10.1029/2003JB002607.

Namson, J. S., and T. L. Davis (1988), Seismically active fold and thrust belt in the San Joaquin Valley, central California, Geological Society of America Bulletin, 100, 257-273.

Rymer, M. J., and W. L. Ellsworth (1990), edited, The Coalinga, California, Earthquake of May 2, 1983, U.S. Geological Surv. Prof. pap. 1487.

Rymer, M. J., K. J. Kendrick, J. J. Lienkaemper, and M. M. Clark (1990a), The Nuñez fault and its surface rupture during the Coalinga earthquake sequence, in Rymer, M. J. and W. L. Ellsworth, ed., The Coalinga, California, Earthquake of May 2, 1983, U.S. Geol. Surv. Prof.. pap. 1487, pp. 299-318. 
Rymer, M. J., J. J. Lienkaemper, and B. D. Brown (1990b), Distribution and timing of slip along the Nuñez fault after June 11, 1983, in Rymer, M. J. and W. L. Ellsworth, ed., The Coalinga, California, Earthquake of May 2, 1983, U.S. Geol. Surv. Prof.. pap. 1487, pp. 319-334.

Stein, R. S., and G. E. Ekström (1992), Seismicity and geometry of a 110-km long blind thrust fault, 2, Synthesis of the 1982-85 California earthquake sequence, J. Geophys. Res., 97, 4865-4883.

Stein, R. S., and G. C. P. King (1984), Seismic potential revealed by surface folding: The 1983 Coalinga, California, earthquake, Science, 224, 869-872.

Stein, R. S., and R. S. Yeats (1989), Hidden Earthquakes, Sci. Am., 260, 48-57, June.

Wentworth, C. M., and M. D., Zoback (1990), Structure of the Coalinga area and thrust origin of the earthquake, in Rymer, M. J. and W. L. Ellsworth, ed., The Coalinga, California, Earthquake of May 2, 1983, U.S. Geol. Surv. Prof.. pap. 1487, pp. 41-68. 


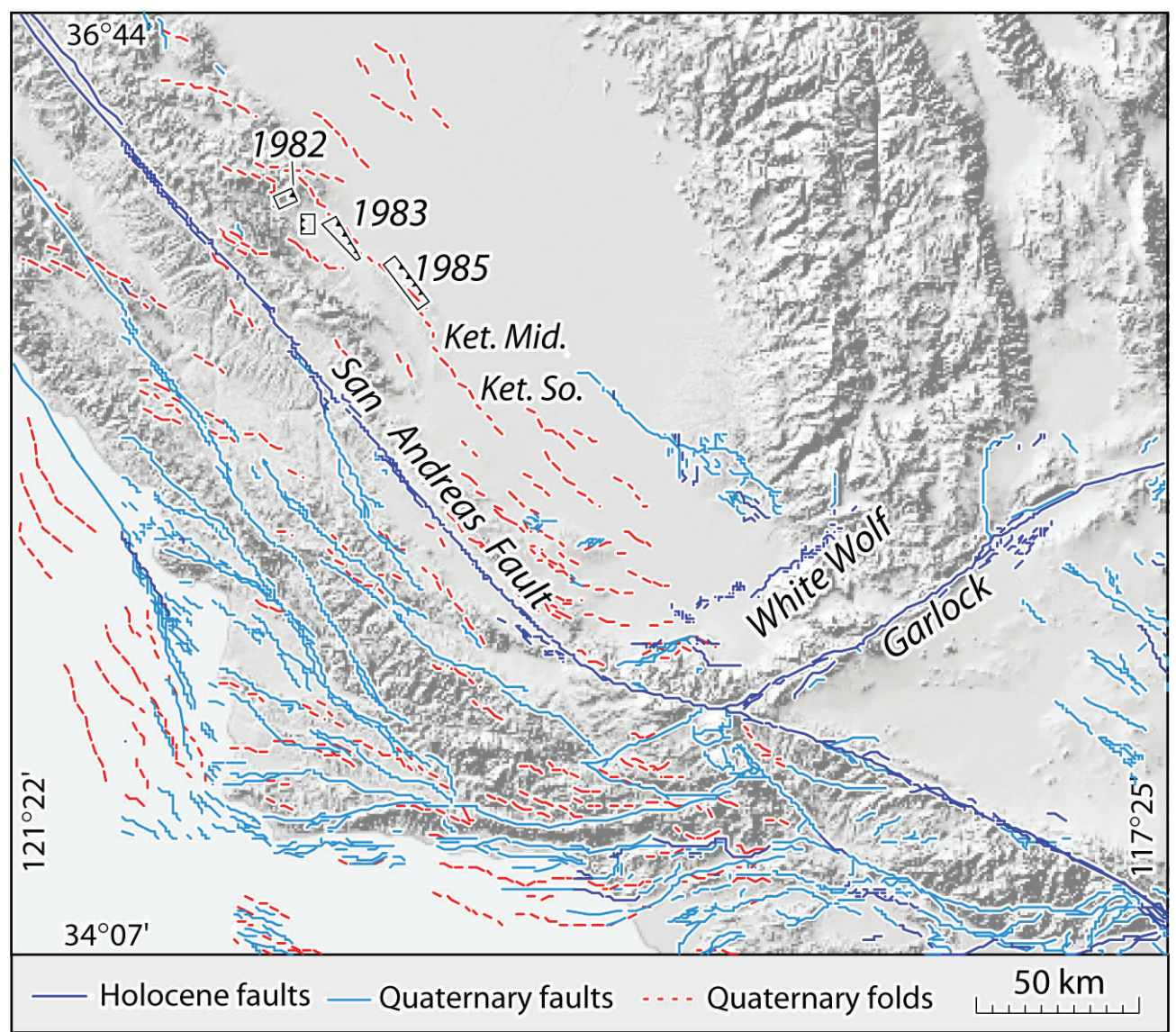

Figure 1. Active faults and folds in central and southern California modified from Lin and Stein [2004]. Shown are locations of the 1982 New Idria, 1983 Nuñez and Coalinga, and 1985 Kettleman Hills earthquakes. Ket. Mid., Kettleman Middle Dome; Ket. So., Kettleman South Dome. Quaternary folds are surrogates for blind thrust faults. They extend parallel to the San Andreas fault nearly as far south as the White Wolf reverse fault. 

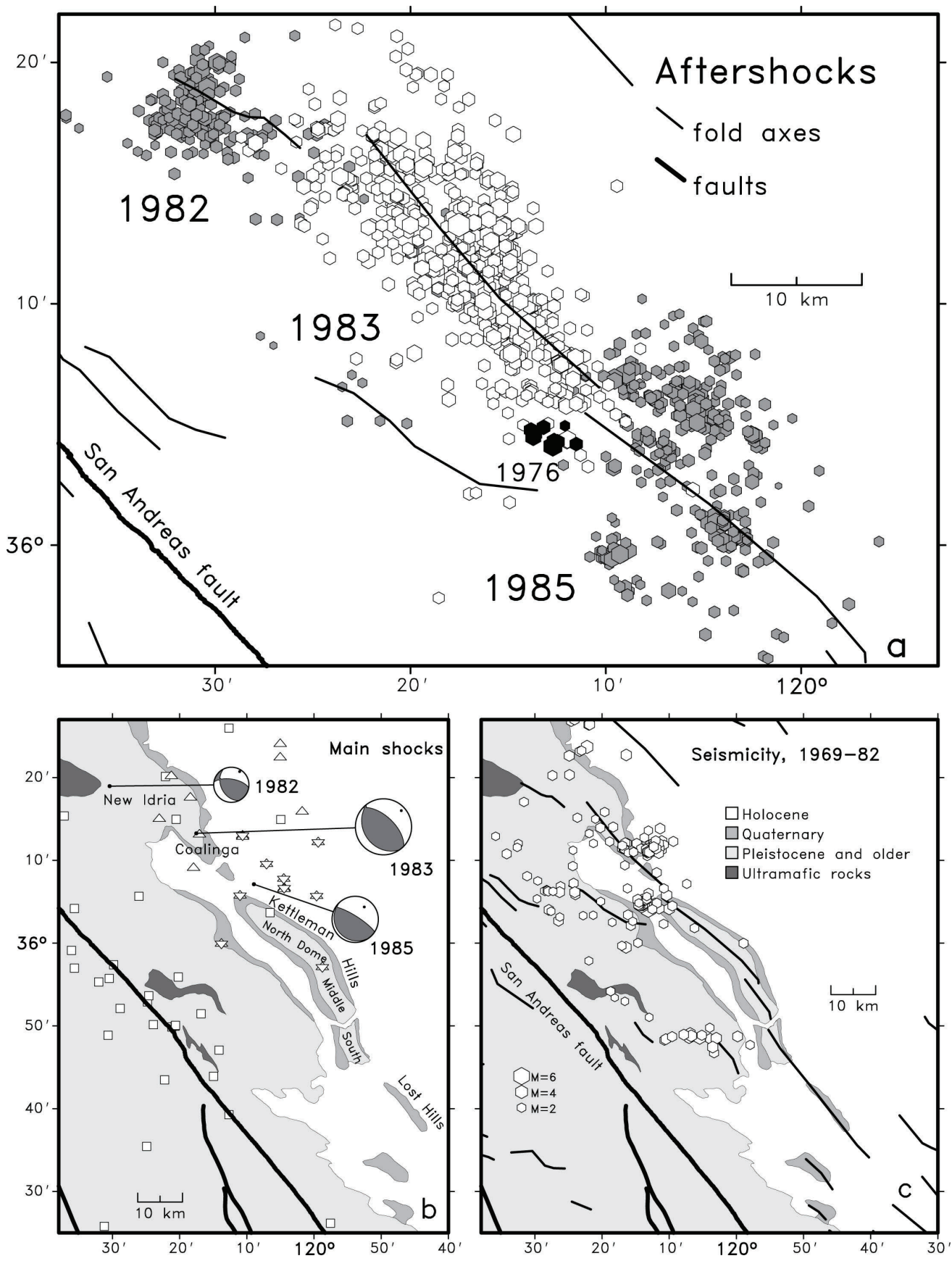

Figure 2. Relocated seismicity of the Coalinga-Kettleman Hills region [Stein and Ekström, 1992].

(a) Relocated aftershock sequence of the 1982 New Idria (shaded hexagons, northwest), 1983 Coalinga (open hexagons), 1985 Kettleman Hills (shaded hexagons, southeast), and the 1976 Polvadero (solid hexagons) earthquakes. (b) Map showing focal mechanism solutions of the 1982 New Idria, 1983 Coalinga, and 1985 Kettleman Hills main shocks together with the seismic stations of the CalNet network from which the data are used to locate the earthquakes. Station symbols: permanent (squares), temporary stations in 1983 (triangles), and temporary stations in 1985 (stars). (c) Relocated pre-1983 seismicity 10-60 km northeast of the San Andreas fault during 1969 to September 1982 (location error $\leq 1.5 \mathrm{~km}$ ). 


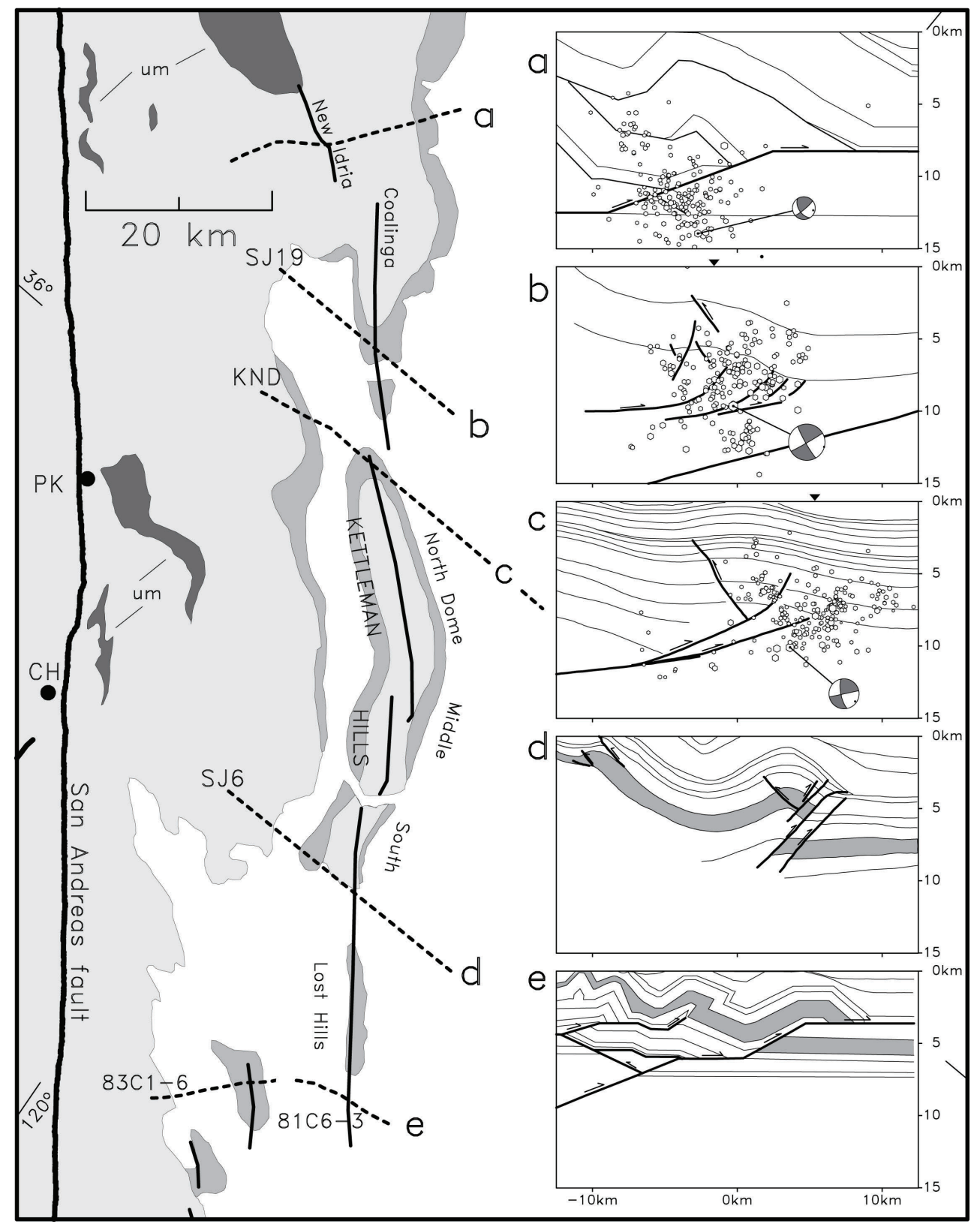

Figure 3. Structural and interpreted seismic cross sections of the Coalinga-Kettleman Hills region [Stein and Ekström, 1992]. The cross sections are projected approximately normal to the fold axis at (a) New Idria, (b) Coalinga, (c) Kettleman Hills North Dome, (d) Kettleman Hills South Dome, and (e) Lost Hills. In panels a-c, a subset of aftershocks are projected together with back-hemisphere projections of the main shocks. PK, Parkfield; $\mathrm{CH}$, Cholame. Panel (a) is a balanced section constructed from oil well logs by Namson and Davis [1988], while the other panels are based on interpretation of seismic reflection and refraction data supplemented by oil well logs. 


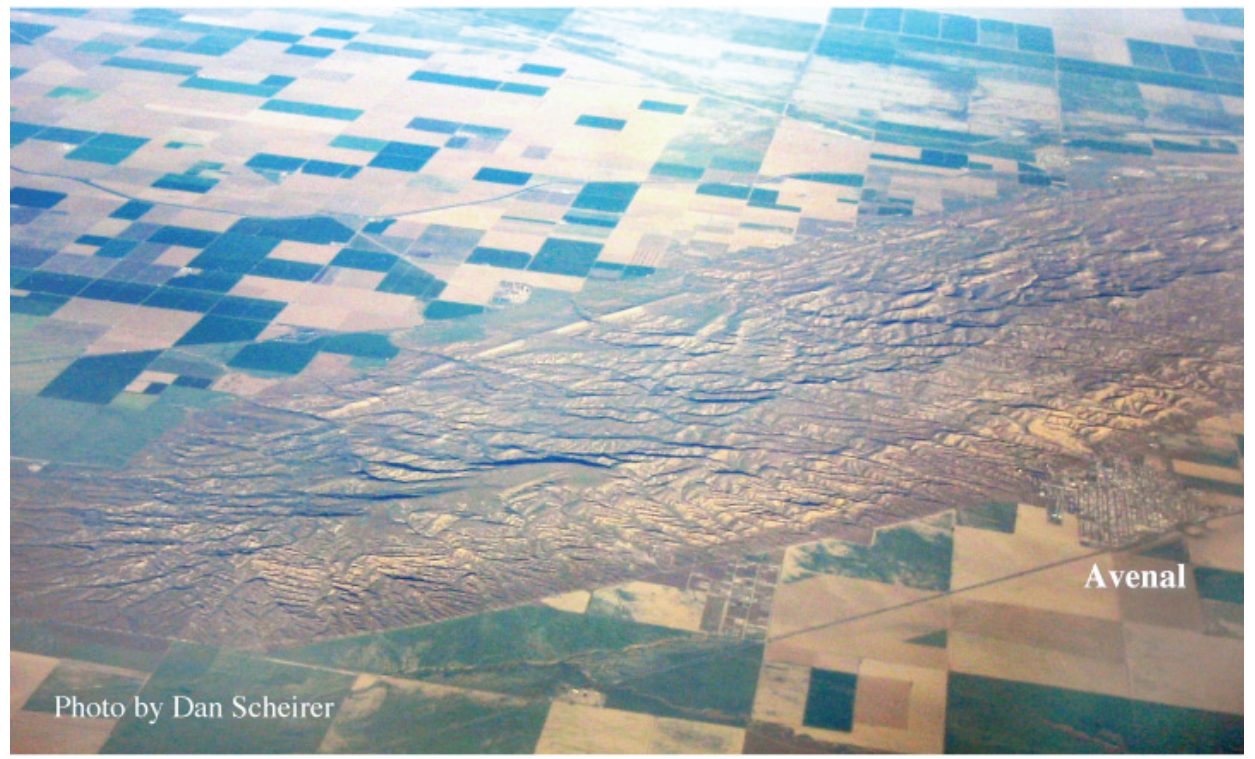

Figure 4. Photo of the Kettleman Hills North Dome, looking in the southeast direction (courtesy of Dan Scheirer, U.S. Geological Survey).

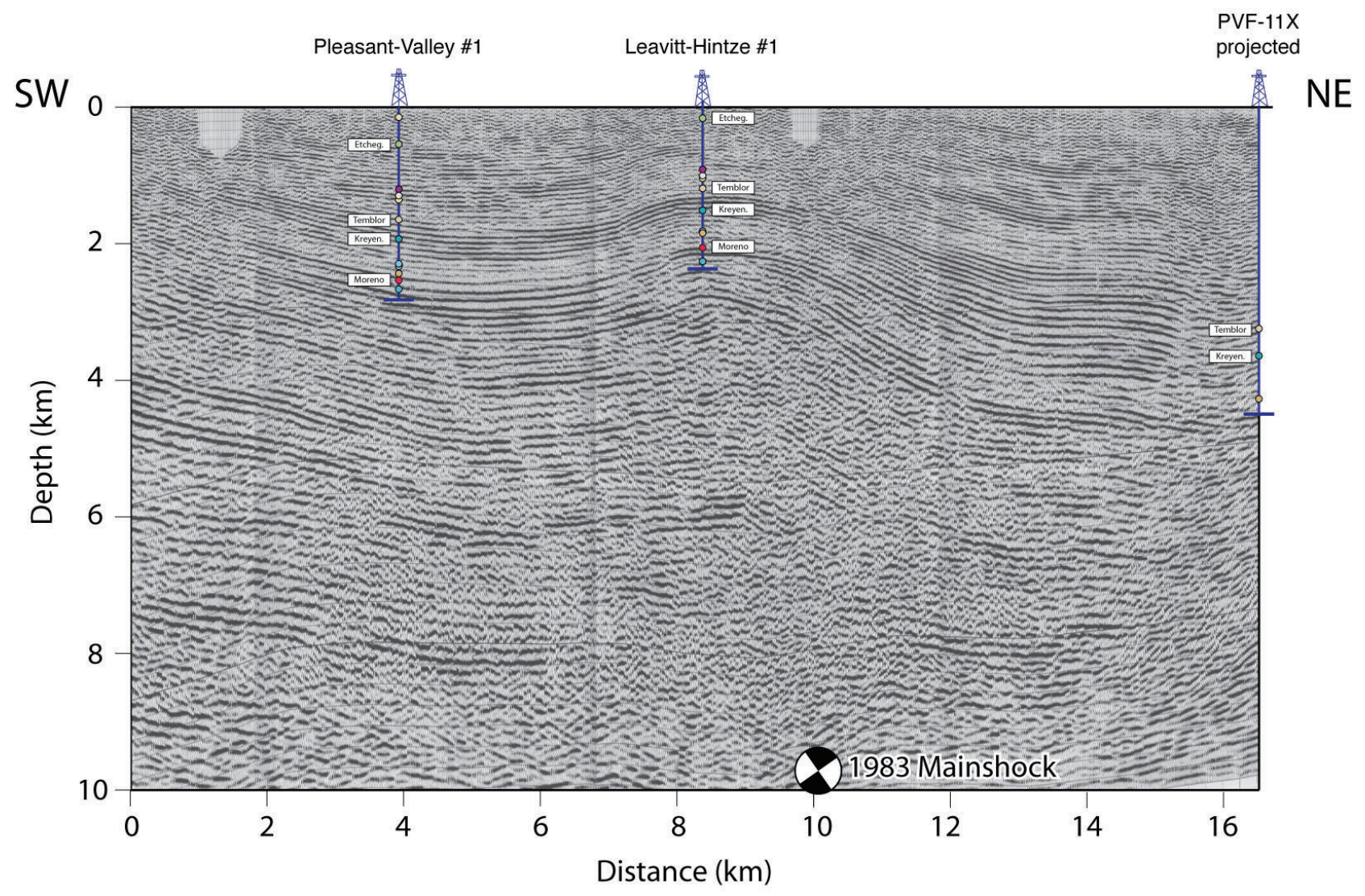

Figure 5. Migrated seismic profile across the Coalinga anticline [Guzofski and Shaw, 2003]. With the possible exception of the anticlinal axis at $2-3 \mathrm{~km}$ depth, $\sim 1 \mathrm{~km} \mathrm{SW}$ of the Leavitt-Hintze \#1 well, there is remarkably little evidence for reverse faulting anywhere in this section. 

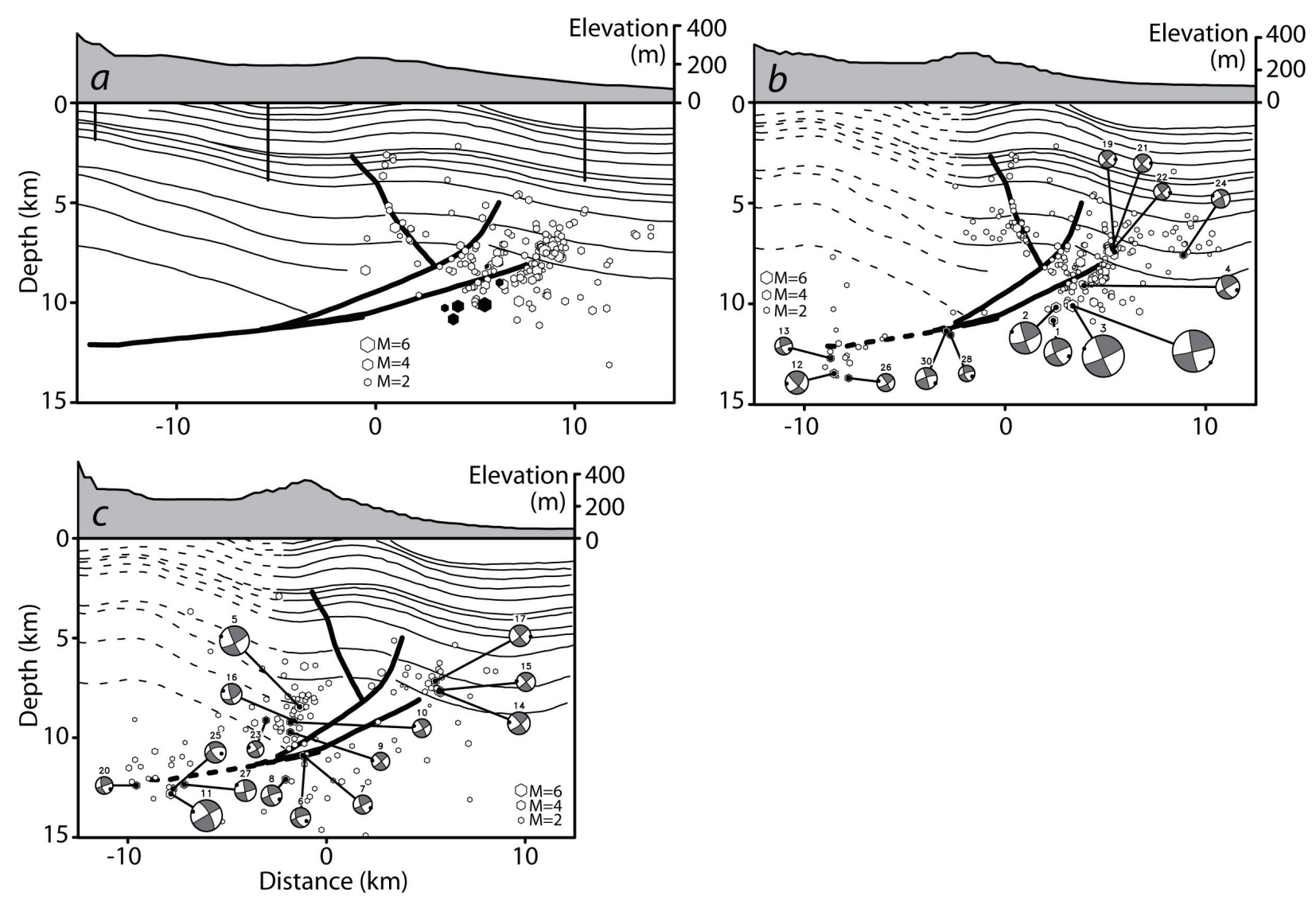

Figure 6. Cross sections showing the subsurface structure and seismicity beneath the Kettleman Hills North Dome region [Ekström et al., 1992]. (a) A cross section beneath a W-E oriented seismic reflection line immediately to the north of the Kettleman North Dome with seismicity superimposed. Small circles show earthquake hypocenters that fall within $3.0 \mathrm{~km}$ horizontal distance from the cross section. The foreshocks and the main shock are shown with solid hexagons. Bedding is shown as thin lines, and faults are shown as thicker lines. The topography is shown above the cross section. Three deep wells used to constrain the interpretation of the section are shown as vertical lines. Only events with vertical and horizontal location uncertainties of less than $1.5 \mathrm{~km}$ are included. (b) Same as in panel a, except both structure and hypocenters have been projected onto a plane perpendicular to the strike of the Coalinga-Kettleman fold axis. The structure to the west is shown as dashed lines, since it may not be representative of the Kettleman North Dome cross section. First motion focal mechanisms are shown in back-hemisphere projection. The unlabeled focal mechanism is the preferred solution for the main shock (event 3), obtained by waveform inversion. (c) Same as panel b, but for the southeastern section of the seismicity in the Kettleman North Dome. 

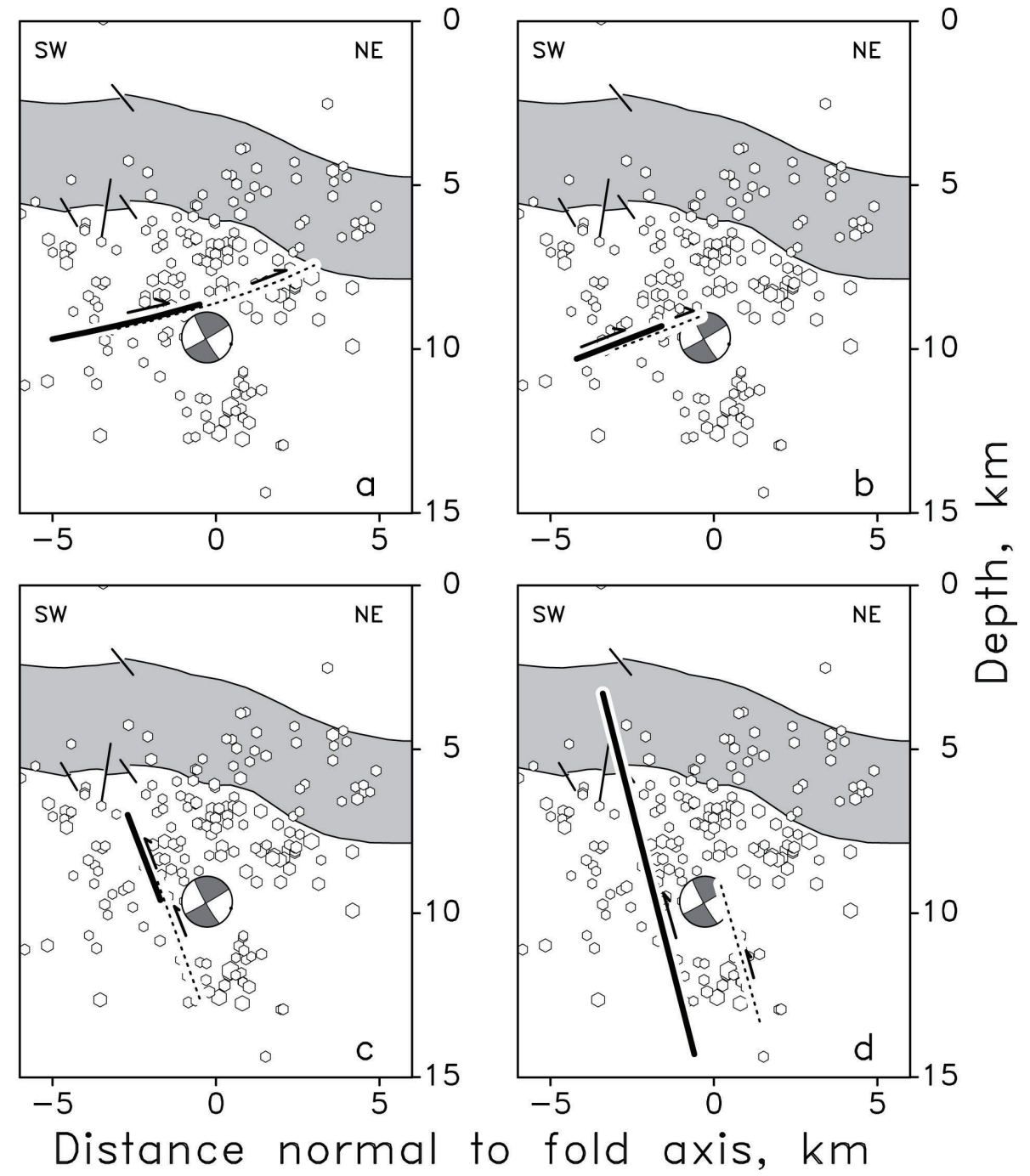

Figure 7. Cross sections of representative dislocation models that satisfy the geodetic data collected in the Coalinga region, together with the back-hemisphere projection of the Coalinga main shock [Stein and Ekström, 1992]. Best-fitting solutions are shown for coseismic displacements (bold lines) and postseismic displacements (dotted lines). The coseismic and postseismic data were collected for the periods February 1972 - June 1983 and June 1983 - July 1987, respectively. The cross sections are projected along the azimuth $\mathrm{N} 55^{\circ} \mathrm{E}$, approximately perpendicular to the Coalinga fold axis. Folded strata and small fault offsets are from seismic reflection profile interpretation. (a) and (b) SW-dipping thrust fault models. (c) and (d) NE-dipping reverse fault models. 

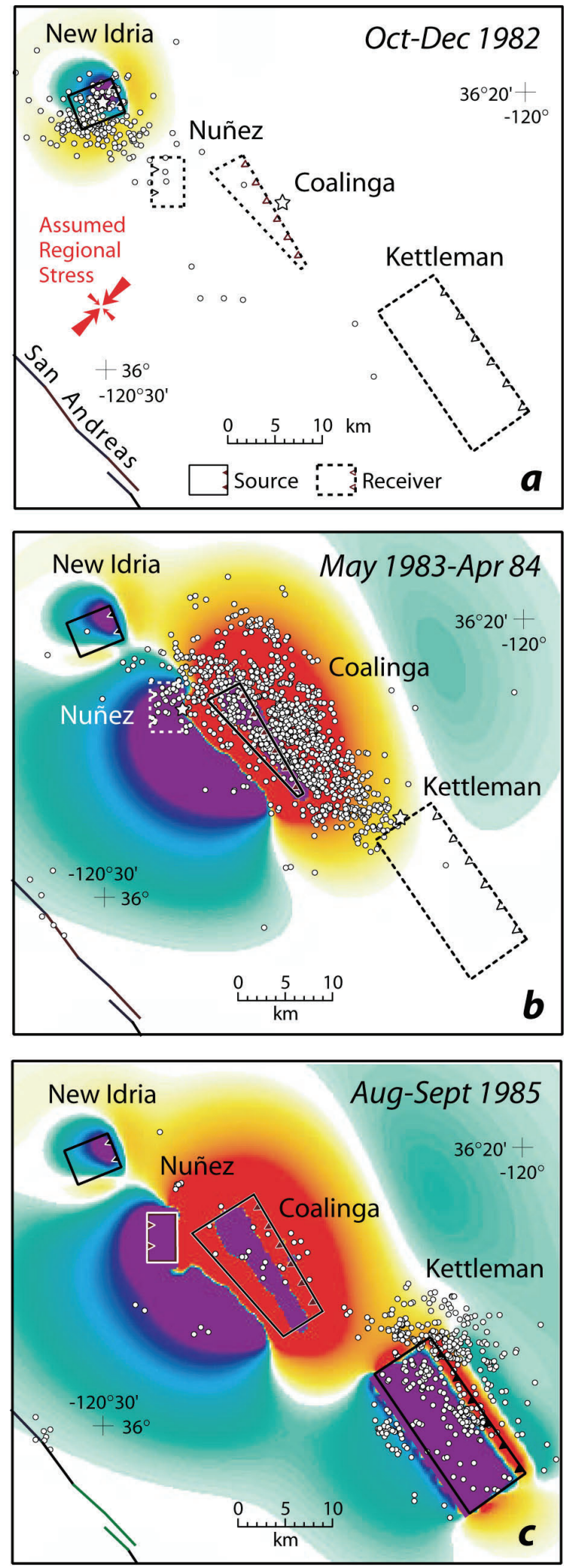

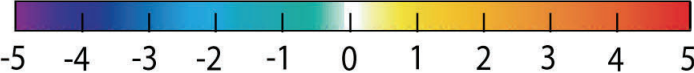
Coulomb Stress Change (bars) on optimally oriented thrust faults at $9 \mathrm{~km}$ depth for $\mu=0.8$
Figure 8. Relationship between the 1983-1985 earthquake sequence and the calculated changes in Coulomb stress changes [Lin and Stein, 2004]. All stress calculations assume receiver faults are optimally oriented for the regional stress with directions shown in panel a. Stresses are shown for a sampling depth of $9 \mathrm{~km}$. (a) Stress from the 25 Oct $1982 \mathrm{M}_{W}=5.8 \mathrm{New}$ Idria earthquake, with aftershocks (25

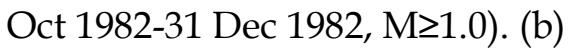
Stress from the New Idria and 2 May $1983 \mathrm{M}_{\mathrm{W}}=6.7$ Coalinga earthquake, with aftershocks of the Coalinga and Nuñez events (2 May 1983-24 April 1984, $\mathrm{M} \geq 2.0$ ). The Coalinga shock brings both the 22 July $1983 \mathrm{M}_{\mathrm{W}}=6.0$ Nuñez and 4 Aug $1985 \mathrm{M}_{\mathrm{W}}=6.0$ Kettleman Hills faults closer to failure. (c) Stress from the New Idria, Coalinga, Nuñez and Kettleman Hills earthquakes, with aftershocks of the Kettleman Hills event (3 Aug 1985-15





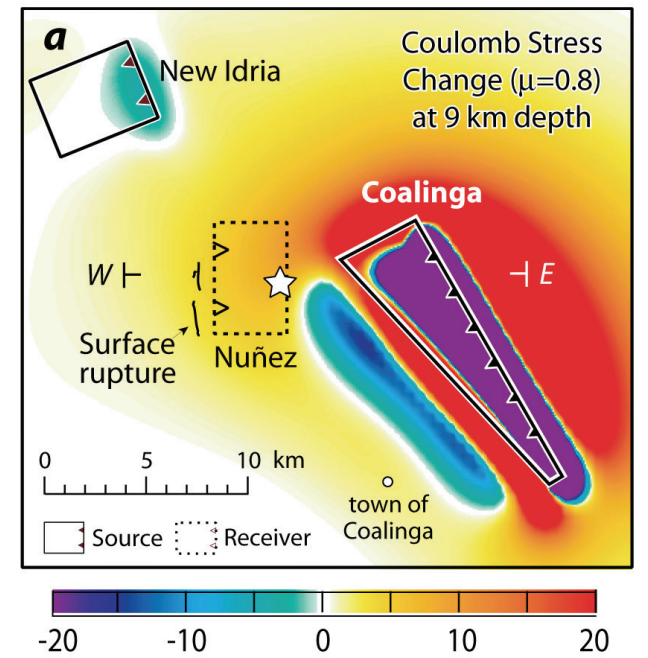

Stress Change (bars) resolved onto Nuñez fault
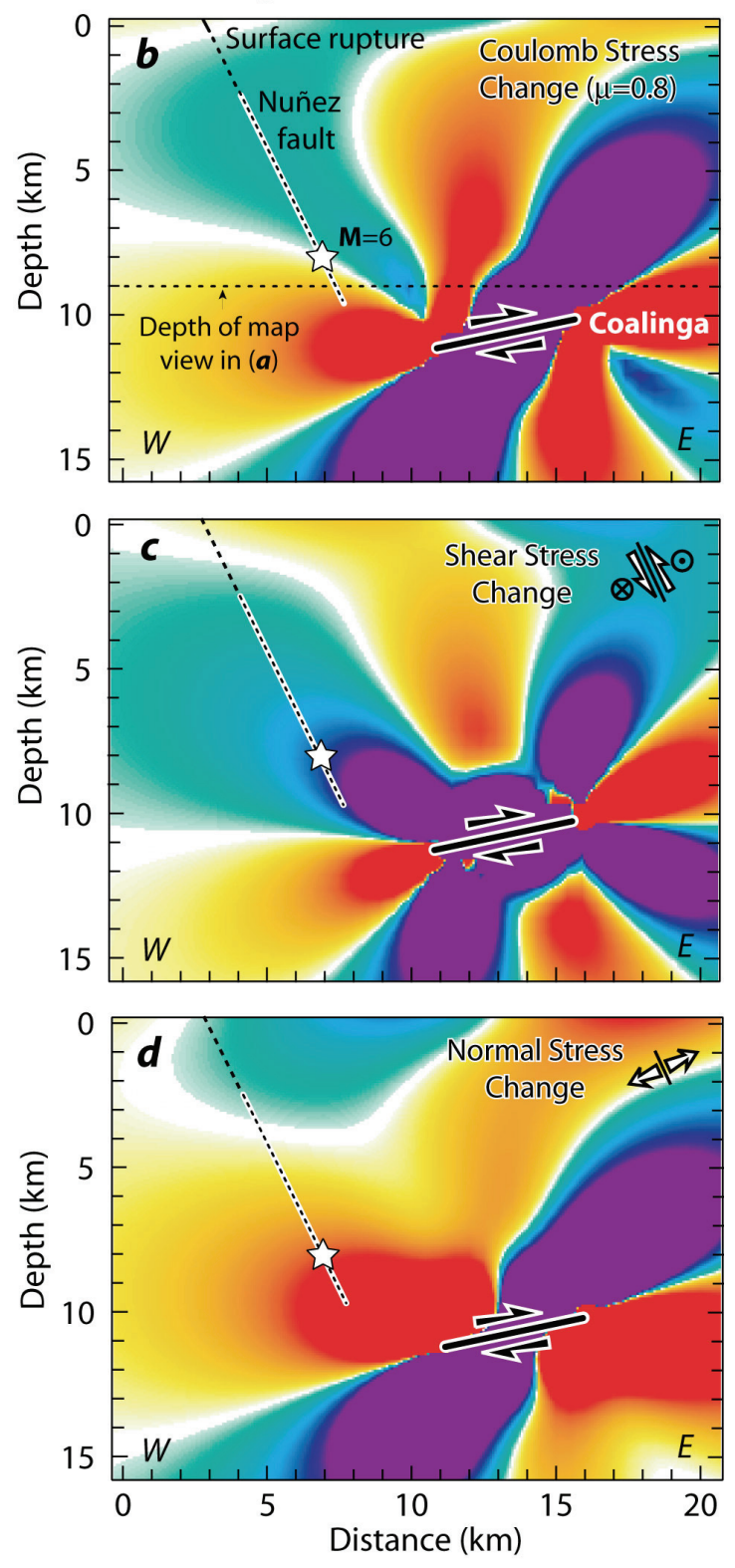

Figure 9. Stress changes caused by the $1982 \mathrm{M}_{\mathrm{W}}=5.8 \mathrm{New}$ Idria and $1983 \mathrm{M}_{\mathrm{W}}=6.7$ Coalinga source faults resolved onto the plane of the subsequent $1983 \mathrm{M}_{\mathrm{W}}=6.0$ Nuñez rupture [Lin and Stein, 2004]. (a) Map view of Coulomb stress changes at 9 $\mathrm{km}$ depth. (b) Coulomb stress changes, (c) shear stress changes, and (d) unclamping in cross-section resolved on the Nuñez rupture plane. The resultant stress components are shown graphically in the upper right hand corners. 

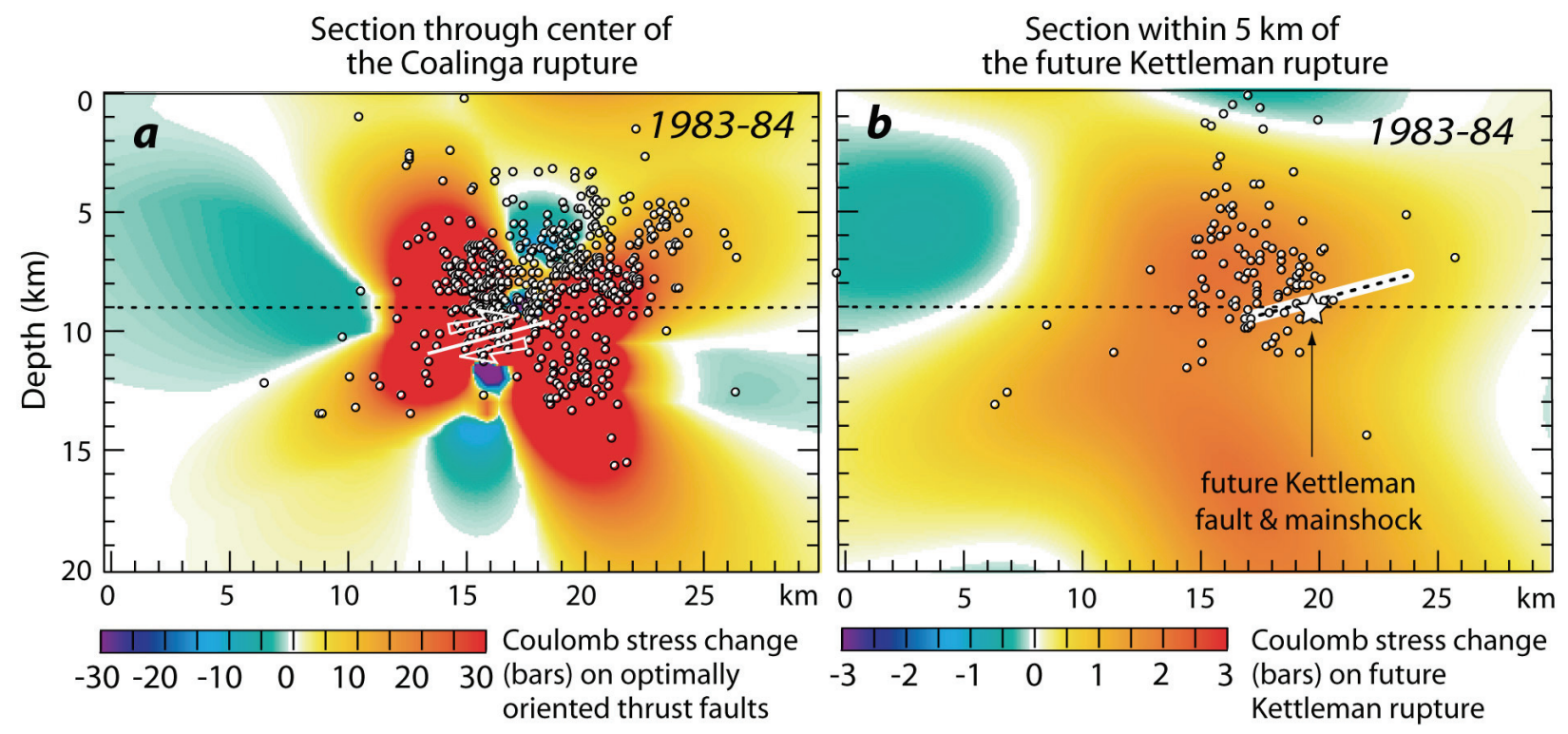

Figure 10. Stress changes caused by the $1983 \mathrm{M}_{\mathrm{W}}=6.7$ Coalinga and $\mathrm{M}_{\mathrm{W}}=6.0$ Nuñez ruptures [Lin and Stein, 2004]. The Coalinga source includes postseismic slip that occurred before the 1985 $\mathrm{M}_{\mathrm{W}}=6.0$ Kettleman Hills rupture. (a) Coulomb stress changes along a cross section cutting through the center of the Coalinga rupture zone, together with aftershocks along an 8-km-wide band. (b) Coulomb stress changes along a cross section within $5 \mathrm{~km}$ north of the future Kettleman Hills epicenter, together with aftershocks along an 8-km-wide band. Stress is imparted by the Coalinga earthquake, resolved onto the future Kettleman Hills rupture plane. 

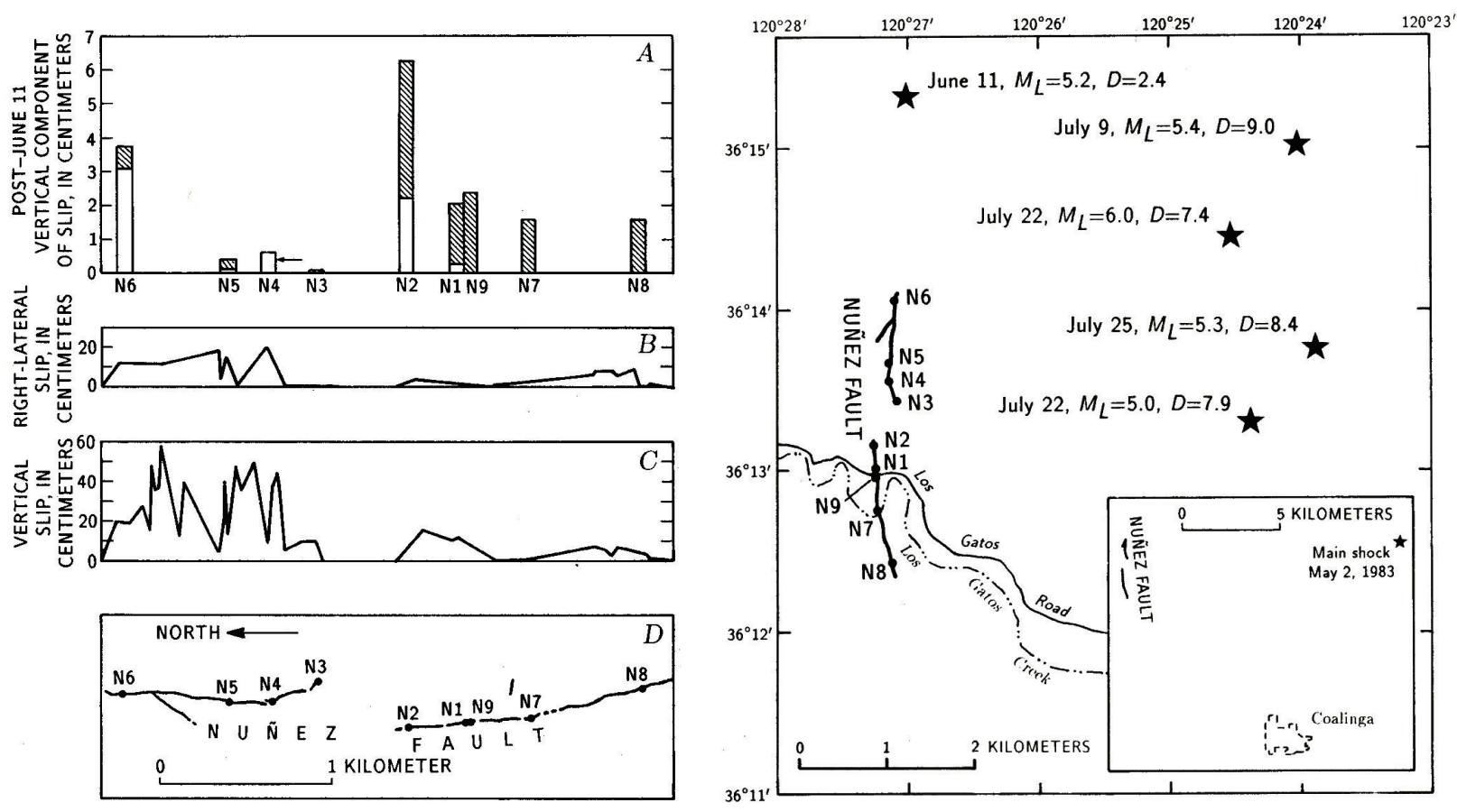

Figure 11. Surface rupture of the Nuñez fault from Rymer et al [1990b]. Left panel: $(A)$

Post-seismic slip; (B), right-lateral slip; (C) vertical slip; (D) map of surface rupture. Right panel: Relationship between Nuñez surface rupture with $M \geq 5$ earthquakes, and with the Coalinga mainshock (inset). The Nuñez fault dips steeply to the east. 